\title{
FARMING IN WESTLAND
}

\author{
J. M. LOCKHART
}

Farm Advisory 0 fficer, Department of Agriculture, Greymouth

THE farmable lands of Westland are oases set in a much larger area of marginal and unfarmable soils, backed by a still larger area of rock and snow. In the Westland land district, approximately 345,000 acres (8.3\%) of the land is farmable; 377,000 acres $(8.5 \%$.) can be described as marginal — giving that word a generous meaning - and the balance, $3,394,000$ acres $(83 \%)$ ) is considered entirely unsuited to farming. This is well illustrated in a map showing the farmable areas which accompanies a report prepared by the N.Z. Department of Lands and Survey ( 1956).

This excellent publication is essential reading for anyone who wishes to understand the problems of this region, though the area under survey included Karamea, Buller, Inangahua and only part of Westland land district.

Various estimates have been made of the future farm production. of Westland. Most are agreed that a fourfold increase is possible with a threefold increase likely over the next twenty-five to thirty years. These increases are from lands al ready farmed and rates per acre al ready achieved by a few farmers. No account has been taken of possible future, technical advances or of extension of farming into lands at present regarded as unsuitable. All this points to Westland as being a farming area with a worthwhile future. Much, moreover, has al ready been achieved in recent years as is indicated in Table 1. The figures quoted were the latest available at the time of preparation. The increases indicated are well above national average and remarkable for a district that has, as yet, not had large areas under Government land development schemes. The high percentage changes are influenced by low starting figures but the trends indicated are continuing.

Dairy cow numbers have been static but it is obvious that there has been a big increase in "per cow production" through better feeding and particularly better winter feeding. At one time, "per-cow production" was far below national average. Judging by the number of bobby calves collected last season, there has been a recent increase in cow numbers. Increase in stocking rate, to improve utilization, should be the next step on the majority of farms now that more and better feed is being grown. 
ProceEdings N.Z. GRASSLAND ASSOCIATION

TABLE 1: WESTLAND LAND DISTRICT PASTORAL STATISTICS

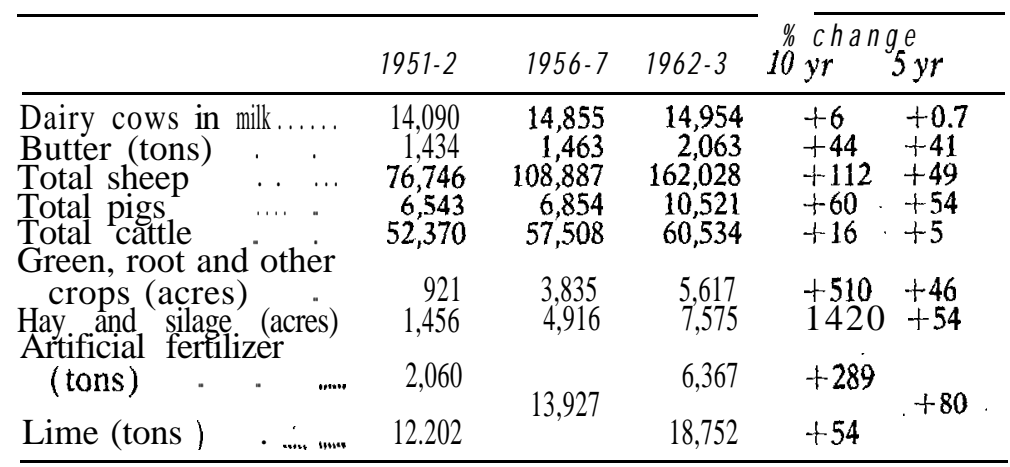

Total cattle numbers show little change but beef production has gone up with the switch to sale of younger fat stock.

The fodder crop figures may not indicate progress to those who believe that "all-grass" farming is the correct practice under a high rainfall. Most of this crop. is grown, in the breaking-in of land, from old clearings now in rough grass and stumps, old river courses and "second growth" country. Once this development stage is over, it should be possible to abandon the winter crop. With the mild winter climate, feed requirements are not high, and,- under improved soil-fertility conditions, there is a long growing season. The recommended North Island practice of consuming all conserved feed at the start of winter cannot be slavishly followed because a very wet. spring that slows down growth is. not uncommon - wet by even Westland and Buller standards.

The new techniques in silage -making, plus self feeding, fit extremely well into local dairy farm management and also with beef cattle raising, as. is being demonstrated. The loafing barn and feedyard can be adopted also, for, although winter pugging is not as severe as in the 'Hauraki or the wetter parts of Taranaki, pastures can be badly damaged.

The basic reason for these increases in farming activity and production, is a change in attitude towards farming. More local farmers now have. confidence in the land to produce, at least, on a level with other, grassland districts. Underlying this change is the desire for. a higher standard. of living. A decade ago, Westland farming folk seemed prepared to accept a lower standard of living. Dairy farmers were satisfied with a production of 7,000 to $10,000 \mathrm{lb}$ butter- 
TABLE 2: WESTLAND LAND DISTRICT 
fat per year when farmers in the rest of $\mathrm{New}$ Zealand were aiming at 14,000 to $16,000 \mathrm{lb}$. N ow that the national target aim is higher, the gap between the two has closed.

As a general statement, Westland's farmers, today, show a better knowledge of improved farming methods. The desire to learn is high; the demand for advisory service cannot be fully met: The presence of "improvers" has helped pave the way more than any other factor. In each of the farming districts, one can point to a few farmers that led the way. Some of these men were new to the district; a few were returned servicemen ; a few were farmers' sons ; and some, strangely enough, were men who had been farming in an indifferent fashion all their days and who suddenly took a new lease of life. Unfortunately, the virus that affected this latter group is not very infectious.

The erection of flood protection works by the Westland Catchment Board in several districts has encouraged farmers to develop land previously under constant threat. It has also provided the confidence required to further develop land al ready farmed. Protection from flood damage is of extreme importance in this region where flood flows are high, and where nearly all of the good land is confined to old flood plains. Extreme peak flows of the various local rivers are up to 300,000 cusecs for the Grey ; 200,000 cusecs for the Hokitika, while the Buler, just outside the land district., could exceed 400,000 cusecs. This is in contrast to the Waimakariri, 180,000; Clutha, 200,000; and Manawatu, 150,000 cusecs.

Drainage schemes supervised by the Catchment Board have increaseed the amount of farmable land available. These schemes have so far provided outfall to approximately 17,000 acres. Characteristic of all schemes so far, is that the need for subsidiary drainage has been far less than anticipated, and the land has been ready for development earlier than expected.

It is probable that the example of the State, in successfully developing land that was not highly regarded, has encouraged others to do likewise but an important ancillary of State activity has been the encouragement of farm contractors. Contracts let by the State helped start farm contractors off and, with these, and others who started off on bush and road work, there are now many good operators available. The contractor with his heavy equipment can do land development work cheaper and quicker than the farmer with light equipment. It does not pay the 
farmer to purchase heavy machinery to lie idle most of the year.

Government land development was responsible for an increase of about 15,000 of the sheep noted in Table 1 . More rapid increases from this source have since occurred as, with the purchase of areas of better soils, development is proceeding at a faster rate. Until comparatively recently, there was virtually no Crown land suitable for development in Westland. Some of the present blocks are on poor soils where settlement should not be rushed. Nevertheless, the eventual occupation of approximately 40 dairy units and 17 sheep units now under development will be a valuable help. It is to be hoped that, when these farms come up for ballot, more interest will be shown than in the past.

Few people in the district realize the contribution that assistance under the Marginal Lands Act has made. $£ 120,000$ has been taken up in fifty-one loans in a district in which there are only about 450 potentially economic units. In only two cases can it be said that the loans have not achieved their purpose; in four other cases, full repayment will be difficult to meet ; but the balance of the borrowers are being left in a much better financial position and with increased income, It must be remembered that these are loan propositions that have been turned down by other lending institutions: The success of these loans must have influenced the policy of other lending bodies.

Despite the increases achieved, one would need permanently fixed, rose-coloured contact lenses to say that all was right with farming in Westland. It is obvious, to even the casual observer, that there is a large amount of idle, good land in the Westland land district. The position is even worse than it looks at first glance. Table 2 gives some idea of the state of affairs.

Most of the headings in Table 2 are self explanatory. The standards which have been set for an economic unit are $20,000 \mathrm{lb}$ butterfat and 1,000 ewes or their equivalent in sheep and cattle. The figures were compiled from the lists used by the Government Statistician in collecting data for a report on farm production statistics ( 1964). The estimates of potential-are-those-of-the--writer

It should be noted that the Lands and Survey Department holdings are not included.

Table 2 shows only part of the picture, for many of the holdings farmed full-time are in a neglected state. The finger is usually pointed at the large holding but, in the aggregate, much more idle land exists on small holdings. 
Many of the farmers running the largest farms are still increasing production and bringing in new blocks though they are getting a smaller return than the Inland Revenue Department.

For many years, it has been the policy of West Coast Provincial Federated Farmers to press for compulsory acquisition of farm lands. Their voice has been but "a cry in the wilderness". Anyone who has the slightest wish to see land made proper use of, or who has some regard for the welfare of the region, must have sympathy with their attitude. The betterment rate, as suggested by the West Coast Committee of Inquiry (1960), appears to have the most virtue of any suggestion offered, and as long as local farmers have the main voice in its operation it could function quite well. It is certain that, if the local situation applied nationally, legislation would have been enacted long ago.

The unavailability of finance and high interest rates arc often cited as being a bar to farming progress in Westland (as well as elsewhere). Finance is available from the Marginal Lands Board. Money from this source has been advanced under conditions that would give ulcers to any orthodox financier in the country. Applications, before - being turned down, are given the most thorough investigation. The quality of the farmed land and the farmers of Westland are such that they do not need to be carried by the rest of the country - the return on investment is as good as that on any other pasture land in New Zealand.

A special low rate of interest for the region would bc transferred, eventually, to the price of the land and prove most advantageous to the last person whom it was desired to benefit.

One of the biggest bars to progress is the local attitude to borrowing. "Now that the farm is our own we can spend money on development" is announced with pride-the completion of this sentence is - "and in" a few years we will not want to".

What is required are a few farm buyers with a bit more than a second-hand jalopy to realize on - so that they can get into improvement work right away. There are not many farms coming on to the market at any one time, but quite a few properties of good potential have changed hands in recent years, at reasonable prices.

Taxation is often given as the reason for not farming at a higher level of production in Westland. Unfortunately, this is true in only a few cases. If many are really paying at 
a crippling rate then accountants are not earning their fees. However, the very people who are paying high rates are the people in the best position to increase production rapidly.

The climate, and its reputation, does hinder farming, particularly where land improvement, work is concerned. But it confers some advantages, the chief of which is its reliability for growing grass. The importance of this needs no stressing.

With regard to access and transport costs, road improve ments work is offering some relief and the National Roads Board appears to appreciate the Coast's needs. Large subsidies in the form of concession rates and national railways have been suggested. Eventually, however, this type of subsidy, if a permanent feature, would be incorporated into the price of the land. The present Lime Transport Assistance for previously unlimed ground is an essential aid to land development in the area.

Size of unit has most influence on the prosperity of farming. In Westland, the unit standard previously set is too small. Extra income has to be available to meet increased costs. The Lands and Survey units, for instance, could have a target level of at least 30,000 lb butterfat. This would attract settlers with more than the minimum leasehold deposit and give them extra hope for the future.

Cost of secondary schooling is one of the main bars to interest in settling units from $\mathrm{Hari} \mathrm{Hari}$, southwards. Farmers with young families are those needed to go on to the farms.

It is appropriate at this point, to review what has been attempted in extension work in the past eight years. Table 3 summarizes the extent of such work in the period March 1956 to March 1964.

In the first group in Table 3 (farm management advice), a thorough inspection of the farm has been made and a plan agreed upon with the farmer-a plan involving most facets of farm activity. What has been done in most cases is to help the farmer crystalize his own thoughts.

Farms in the second group (technical advice only) may have been. visited quite often but each time the object has been to give specific advice on one subject or several unrelated subjects.

About onethird of the people in the third group (no contact on farm) have been met at the office, at farm schools and at "post- 6 p.m." conferences. With the remainder, there has been no contact. 
TABLE 3: ADVISORY WORK

FARMS VISITED (GREYMOUTH INSTRUCTORATE)

MARCH, 1956, to MARCH, 1964

\begin{tabular}{|c|c|c|c|c|c|c|}
\hline \multirow[b]{2}{*}{$\begin{array}{l}\text { Potentially } \\
\text { economic } \\
\text { rnits farmed } \\
\text { full-time }\end{array}$} & \multirow[b]{2}{*}{$\begin{array}{l}\text { Grey } \\
\text { Westland }\end{array}$} & \multirow{2}{*}{$\begin{array}{c}\begin{array}{c}\text { Farm } \\
\text { Management } \\
\text { Advice }\end{array} \\
70 \\
96\end{array}$} & \multirow{2}{*}{$\begin{array}{c}\begin{array}{c}\text { Technical } \\
\text { Advice } \\
\text { Only }\end{array} \\
34 \\
92 \\
92\end{array}$} & \multirow{2}{*}{$\begin{array}{c}\begin{array}{c}\text { No Contact } \\
\text { on Farm }\end{array} \\
\begin{array}{c}14 \\
63\end{array}\end{array}$} & \multicolumn{2}{|c|}{ Total } \\
\hline & & & & & $\left.\begin{array}{l}118 \\
251\end{array}\right\}$ & 369 \\
\hline $\begin{array}{l}\text { Potentially } \\
\text { unkconomic } \\
\text { units farmed } \\
\text { full-time }\end{array}$ & $\begin{array}{l}\text { Grey } \\
\text { Westland }\end{array}$ & $\begin{array}{l}7 \\
5\end{array}$ & $\begin{array}{r}4 \\
10\end{array}$ & $\begin{array}{r}3 \\
11\end{array}$ & $\left.\frac{14}{26}\right\}$ & 40 \\
\hline $\begin{array}{l}\text { Potentially } \\
\text { economic } \\
\text { units farmed } \\
\text { part-time }\end{array}$ & $\begin{array}{l}\text { Grev } \\
\text { Westland }\end{array}$ & $\begin{array}{l}8 \\
2\end{array}$ & $\begin{array}{l}8 \\
8\end{array}$ & $\begin{array}{l}8 \\
5\end{array}$ & $\begin{array}{l}24\} \\
15\}\end{array}$ & 39 \\
\hline \multirow{2}{*}{$\begin{array}{l}\text { Potentially } \\
\text { unkconomic } \\
\text { units farmed } \\
\text { part-time }\end{array}$} & $\begin{array}{l}\text { Grev } \\
\text { Westland }\end{array}$ & $1 \frac{1}{3}$ & 23 & 24 & $\begin{array}{l}58\} \\
39\end{array}$ & 97 \\
\hline & & 202 & 191 & 152 & & 545 \\
\hline
\end{tabular}


Active agricultural extension workers in the district could help Westland farmers, but intensive advice cannot be given by one officer only. At present, technical improvements are paralleled by increased profits but with further advances the margins will become less. It is to be hoped that all accountants can be persuaded to adopt standard accounting procedures and farmers come to realize that they should pay for this extra service. Only in this way can convincing evidence be obtained of the rewards of farm improvement.

Because of the small area of land available, Westland will never produce more than a relatively small percentage of New Zealand's total primary production -but it is essential to the prosperity of the region that better use be made of its farming resources.

\section{REFERENCES}

Committee of Inqiiiry, 1960: Report on the West Coast. Govt. Printer, Wellington.

Department of Statistics, 1964: Report on the Farm Production Statistics for the Season 1962-63.

N.Z. Department of Lands and Survey, 1956: Report on Land Utilisation Survey, West Coast Region, South Island, N.Z. 